\title{
Omega-3-Fatty Acid Concentration in Portulaca oleracea is Altered by Nitrogen Source in Hydroponic Solution
}

\author{
Usha Rani Palaniswamy, ${ }^{1}$ Richard J. McAvoy, ${ }^{2}$ and Bernard B. Bible ${ }^{2}$ \\ University of Connecticut, Storrs, CT 06269-4067
}

\begin{abstract}
ADDITIONAL INDEX wORDs. $\alpha$-linolenic acid, linoleic acid, nitrate to ammonium ratio
Abstract. Purslane (Portulaca oleracea L.) has been identified as an exceptionally rich source of $\alpha$-linolenic acid (LNA), an essential fatty acid that is beneficial in reducing the incidence of coronary heart disease and certain cancers. In general, about two thirds of the LNA in terrestrial plants is associated with chloroplasts. A green-leafed unnamed cultivar of purslane and a golden-leafed cultivar 'Goldberg' were grown hydroponically in a complete nutrient solution with $14.3 \mathrm{~mm}$ nitrogen provided as nitrate $\left(\mathrm{NO}_{3}{ }^{-}\right)$and ammonium $\left(\mathrm{NH}_{4}{ }^{+}\right)$forms to yield $\mathrm{NO}_{3}^{-}-\mathrm{N}$ : $\mathrm{NH}_{4}{ }^{+}-\mathrm{N}$ ratios of 1:0, 0.75:0.25, 0.5:0.5, and 0.25:0.75. Young leaves, harvested 18 days after treatment initiation, were analyzed to determine the fatty acid composition and concentrations, and thylakoid protein and chlorophyll concentrations. Although the leaves of plants grown with a $\mathrm{NO}_{3}$ $-\mathrm{N}: \mathrm{NH}_{4}{ }^{+}-\mathrm{N}$ ratio of $0.5: 0.5$ contained $239 \%$ and 114\% more LNA than plants grown with ratios 1:0 and 0.75:0.25, respectively, they contained only $41 \%$ and $26 \%$ more chlorophyll. The green-leafed cultivar had higher (39\%) chlorophyll concentrations than 'Goldberg', but both cultivars had similar LNA concentrations [per g dry weight (DW)]. These results suggest that the LNA concentration in the fatty acid-rich species $P$. oleracea may not be as closely associated with chlorophyll concentration as reported earlier for other plants. Leaves of plants grown in solutions with $0.25: 0.75 \mathrm{NO}_{3}^{-}-\mathrm{N}^{-} \mathrm{NH}_{4}{ }^{-}-\mathrm{N}_{\text {ratio }}$ contained $35 \%$ less LNA per $g$ leaf $D W$ than the leaves of plants grown in nutrient solutions with a 0.5:0.5 ratio. Although total DW production was not affected by the $\mathrm{NO}_{3}^{-}-\mathrm{N}: \mathrm{NH}_{4}{ }^{+}-\mathrm{N}$ ratios in the nutrient solutions, the green-leafed cultivar produced higher fresh weight, leaf area, total DW, and number of shoots than 'Goldberg'.
\end{abstract}

Although purslane (Portulaca oleracea) has long been known as a nuisance weed (Vengris et al., 1972), more recently strong interest has developed in this species as a highly nutritious salad green or potherb. This interest is encouraged by the perceived health benefits associated with $\alpha$-linolenic acid (LNA), an omega-3 fatty acid $(\omega 3 \mathrm{FA})$ often referred to as fish oil, and the antioxidant $\alpha$-tocopherol. In fact, the health benefits of $\omega 3 \mathrm{FAs}$, as part of a balanced diet, have been well-established (British Nutrition Foundation, 1993; Simopoulos, 1991; Simopoulos et al., 1985). Purslane leaves are a rich source of both the 18:3 fatty acid (LNA) and $\alpha$-tocopherol (Simopoulos et al., 1992). According to Simopoulos et al. (1992) and Simopoulos and Salem (1986), the LNA concentration in purslane leaves is much higher than that found in leafy vegetables such as spinach (Spinacia oleracea L.), butterhead lettuce and leaf lettuce (Lactuca sativa L.), mustard (Brassica juncea L.), sorrel (Rumex acetosa L.), and beet greens (Beta vulgaris L.) and even higher than that found in some commonly consumed fish species (Simopoulos et al., 1985).

$\alpha$-Linolenic acid usually occurs as a critical constituent in chloroplasts (Tremolieres et al., 1979), making up about two thirds of the total fatty acids (TFA) in chloroplasts of photosynthetic tissues (Allen et al., 1966; Crombie, 1958; Wolff, 1966). The high concentration of LNA in purslane is due to its high concentration of total fatty acids and not to an unusual fatty acid composition (Simopoulos et al., 1992). If LNA production in purslane is to be optimized, we need to understand the effects of cultural practices such as mineral nutrient application on LNA accumulation. Nitrogen $(\mathrm{N})$ nutrition of plants could affect chloroplast development with the resultant impact on LNA concentration of leaves.

\footnotetext{
Received for publication 11 June 1999. Accepted for publication 9 Nov. 1999 Storrs Agricultural Experiment Station scientific contribution no. 1887. This research was funded, in part, the University of Connecticut Research Foundation and the Storrs Agricultural Experiment Station. The cost of publishing this paper was defrayed in part by the payment of page charges. Under postal regulations, this paper therefore must be hereby marked advertisement solely to indicate this fact.

${ }^{1}$ School of Allied Health-Asian American Studies Institute.

${ }^{2}$ Department of Plant Science.
}

Increased $\mathrm{N}$ levels increased the dry weight (DW) and fatty acid production in perennial grasses (Barta, 1975), and the LNA concentration in algae and euglena (Euglena gracilis Z.) (Pohl et al, 1971; Regnault et al., 1995). $\alpha$-Linolenic acid synthesis in pea (Pisum sativum L.) and morning glory (Pharbitis nil L.) increased with increasing chlorophyll synthesis (Tchang et al., 1985; Tremolieres, 1972; Tremolieres et al., 1973), and Raab and Terry (1994) showed that chlorophyll concentration was higher in $\mathrm{NH}_{4}{ }^{+}-\mathrm{N}$ grown plants than in $\mathrm{NO}_{3}^{-}-\mathrm{N}$ grown plants. The source of $\mathrm{N}\left(\mathrm{NO}_{3}^{-}\right.$and/or $\left.\mathrm{NH}_{4}{ }^{+}\right)$ in the growing medium influenced the concentration of fatty acids in lower plants such as green and blue-green algae (Piorreck et al., 1984), and the photosynthetic capacity and DW production of the higher plant, carnation (Dianthus caryophyllus L) (Green and Holley, 1974).

Although these studies show some effects of $\mathrm{N}$ source or $\mathrm{N}$ amounts on plant fatty acid concentration, similar studies have not been reported for a plant like purslane with edible leaves rich in LNA. To fill this void, we determined the fatty acid compostion and concentration, and thylakoid chlorophyll and protein concentrations in leaves of hydroponically grown purslane plants provided with varying ratios of $\mathrm{NO}_{3}{ }^{-}-\mathrm{N}: \mathrm{NH}_{4}{ }^{+}-\mathrm{N}$.

\section{Materials and Methods}

Plant material. Twenty-five-day-old seedlings of two purslane cultivars, a) an unnamed green-leafed cultivar(Valley Seed Service, Fresno, Calif.) andb) 'Goldberg', a golden-leafed cultivar, (Johnny's Selected Seeds, Albion, Maine) were transplanted into a closed hydroponic system in the greenhouse. The cultivars were selected for their upright growth habit and the apparent difference in leaf chlorophyll concentration.

HyDROPONIC SYSTEM. Plants were grown in individual 8-L containers capped with styrofoam platforms $(2.5 \mathrm{~cm}$ thick $\times 30 \mathrm{~cm}$ wide $\times 30 \mathrm{~cm}$ long). The nutrient solution in each container was aerated for $1 \mathrm{~min}$ every $15 \mathrm{~min}$, using a timer-controlled air bubbler. Six purslane seedlings were transplanted onto each styrofoam platform and each 8-L container held a complete nutrient solution 
(Table 1) with $14.3 \mathrm{~mm}$ total $\mathrm{N}$ in one of four $\mathrm{NO}_{3}{ }^{-} \mathrm{N}: \mathrm{NH}_{4}{ }^{+}-\mathrm{N}$ ratios (1:0, 0.75:0.25, 0.5:0.5, and 0.25:0.75). During the experiment, nutrient solution was monitored twice weekly for chemical changes. Due to the large solution volume and small plant mass, solution nutrient content and water volume were not adjusted during the short experimental period. However, $\mathrm{pH}$ adjustments were made whenever the $\mathrm{pH}$ deviated 0.4 units from the set point range (6.6 to 6.8) by adding $0.5 \mathrm{M} \mathrm{HCl}$ or $\mathrm{NaOH}$ as needed.

The four $\mathrm{N}$-form treatments were arranged in a randomized complete block design with five replications of each treatment for each cultivar. The experiment was conducted two times.

Plant growth EnVironment. The initial study began 31 May and plants were harvested 18 June 1996. The second experiment began 27 June and ended 15 July 1996. Environmental conditions were recorded on a Campbell Scientific 21X Datalogger (Campbell Scientific, Logan, Utah) at 1-min intervals using quantum sensors (LI-190-SA; LI-COR, Inc., Lincoln, Neb.) to monitor photosynthetic photon flux $(P P F)$ and copper-constantan thermocouples to monitor air and solution temperatures. The average daily $P P F( \pm \mathrm{SE})$ was $9.25 \pm 0.66 \mathrm{~mol} \cdot \mathrm{m}^{-2} \cdot \mathrm{d}^{-1}$ during the first experiment and $9.30 \pm$ $0.58 \mathrm{~mol} \cdot \mathrm{m}^{-2} \cdot \mathrm{d}^{-1}$ during the second experiment. Canopy air temperature averaged $24.8 \pm 1.6^{\circ} \mathrm{C}$ during the first study and $25 \pm 1.3^{\circ} \mathrm{C}$ during the second. Nutrient solution temperature averaged $24.3 \pm$ $1.4^{\circ} \mathrm{C}$ and $24.6 \pm 1.4^{\circ} \mathrm{C}$ for two studies, respectively. Plants were maintained under ambient $\mathrm{CO}_{2}$.

Purslane plants were harvested after $18 \mathrm{~d}$ (12 to 14 true leaf stage) of growth in the $\mathrm{N}$-form treatment solutions. One plant from each treatment replicate was used to determine whole plant fresh weight, dry weight (DW), leaf area (using a LI-3100 area meter, LI-COR, Inc. Lincoln, Neb.), and the number of side shoots. From the remaining five plants in each treatment replicate, fully expanded young leaves from the third, fourth, and fifth nodes (counting down from the shoot tip), were harvested and divided into two subsamples. One subsample was used to determine whole leaf chlorophyll, and thylakoid chlorophyll and protein concentrations, and the other subsample was used to determine fatty acid composition and concentrations.

ThylaKoID RECOVERY. Thylakoid membranes were recovered from leaf samples by grinding $\approx 4 \mathrm{~g}$ leaf tissue in $20 \mathrm{~mL}$ of a $50 \mathrm{~mm}$ phosphate buffer ( $\mathrm{pH} 7.6$ ) containing $0.4 \mathrm{M}$ sorbitol, $20 \mathrm{~mm} \mathrm{NaCl}, 20$ mм HEPES, and $3 \mathrm{~mm} \mathrm{MgCl}_{2} \bullet 6 \mathrm{H}_{2} \mathrm{O}$ (Berkowitz and Gibbs, 1985; Chapman et al., 1983). The filtrate was centrifuged at $3000 \mathrm{~g}_{\mathrm{n}}$ for 4 min, and the pellet was washed in $20 \mathrm{~mL}$ of a $50 \mathrm{~mm}$ phosphate buffer ( $\mathrm{pH}$ 7.6) containing $20 \mathrm{~mm} \mathrm{NaCl}$, and shaken on ice for $15 \mathrm{~min}$. The thylakoid pellet was recovered following centrifugation at $10,000 g_{\mathrm{n}}$ for $10 \mathrm{~min}$.

Chlorophyll analysis. Thylakoid chlorophyll was determined by suspending a $50-\mu \mathrm{L}$ sample of thylakoid in $4 \mathrm{~mL}$ of $80 \%$ acetone and recording the absorbance at $645 \mathrm{~nm}$ and $663 \mathrm{~nm}$ (Arnon, 1949). Whole leaf chlorophyll was determined by extracting chlorophyll from leaf discs with $\mathrm{N}, \mathrm{N}$-dimethyl formamide and measuring absorption values at $647 \mathrm{~nm}$ and $664 \mathrm{~nm}$ (Inskeep and Bloom, 1985). The ratio of whole leaf chlorophyll to thylakoid chlorophyll was used to determine percent thylakoid recovery for each sample. The recovery factor was used to estimate thylakoid protein on a leaf DW basis.

Protein analysis. Protein concentration was determined using the spectrophotometric procedure of Lowry et al. (1951). A 50- $\mu \mathrm{L}$ sample of thylakoid was suspended in $150 \mathrm{~mL} 0.85 \% \mathrm{NaCl}$ and 2.2 $\mathrm{mL}$ Biuret reagent was added. After $30 \mathrm{~min}, 100 \mu \mathrm{L}$ phenol reagent was added, mixed well, and absorbance was recorded at $750 \mathrm{~nm}$. Thylakoid protein was expressed as $\mathrm{mg} \cdot \mathrm{g}^{-1}$ leaf DW.
Fatty aCid eXtraction, Preparation, AND analyses. Lipids were extracted using the dry column method as follows (Maxwell et al., 1980). Leaf tissue $(\approx 4 \mathrm{~g})$ was homogenized for $30 \mathrm{~s}$ in $25 \mathrm{~mL}$ dichloromethane (DCM):methanol (9:1). The homogenate was mixed with $4 \mathrm{~g}$ anhydrous sodium sulfate and then flushed through a $22 \mathrm{~mm} \times 30 \mathrm{~cm}$ glass column packed with 1:9 calcium phosphate:celite with $150 \mathrm{~mL}$ DCM:methanol (9:1). The filtrate was collected and vacuum dried in a rotary evaporator. The dried lipid fraction was dissolved in $1 \mathrm{~mL} \mathrm{DCM}$ and transferred to $2 \mathrm{~mL}$ glass screw cap vials, flushed with $\mathrm{N}_{2}$ gas, and stored under refrigeration until transesterfication.

The transesterfication procedure of Lepage and Roy (1986) was used to methylate the fatty acid fraction. A $100-\mu \mathrm{L}$ aliquot of extracted lipid was mixed with $2 \mathrm{~mL}$ of an internal standard [100 $\mu \mathrm{L} \cdot \mathrm{mL}^{-1}$ of heptadecanoic acid (a 17:0 fatty acid) in 4 methanol : 1 hexane] and $200 \mu \mathrm{L}$ acetyl chloride in a screw cap test tube. Test tubes were sealed tightly with teflon thread seal tape and heated for $1 \mathrm{~h}$ at $100{ }^{\circ} \mathrm{C}$. After cooling, $5 \mathrm{~mL} 6 \% \mathrm{~K}_{2} \mathrm{CO}_{3}$ was added slowly, mixed, and then centrifuged at $5000 \mathrm{~g}_{\mathrm{n}}$ for $10 \mathrm{~min}$. The lipid layer was removed, completely dried under $\mathrm{N}_{2}$ gas, and then dissolved in $50 \mu \mathrm{L}$ DCM. Finally, the resulting fatty acid methyl esters were injected into a gas chromatograph (Varian 6000, Palo Alto, Calif.) for fatty acid separation and analysis. Fatty acid peak areas were determined with an HP 3395 integrator (Hewlett Packard, Wilmington, Del.) and fatty acids were identified by comparing retention times with standards separated under similar chromatographic conditions [Poly UnsaturatedFatty Acid(PUFA-2), Matreya, Inc., Pleasant Gap, Pa.].

Chromatographic conditions. The gas chromatograph was fitted with Supelcowax capillary column [10 stationary phase, $1 \mu \mathrm{m}$ film thickness, $0.53 \mathrm{~mm} \mathrm{ID} \times 30 \mathrm{~m}$ (Supelco, Bellefonte, $\mathrm{Pa}$.)] and a flame ionization detector. Air and hydrogen flow rates at the detector were maintained at 300 and $30 \mathrm{~mL} \cdot \mathrm{min}^{-1}$, respectively, and the $\mathrm{N}_{2}$ carrier gas flow rate was $1 \mathrm{~mL} \cdot \mathrm{min}^{-1}$. Column temperature gradient increased from 190 to $235^{\circ} \mathrm{C}$ at a rate of $2^{\circ} \mathrm{C} \cdot \mathrm{min}^{-1}$ and ion temperature was held at $240{ }^{\circ} \mathrm{C}$. Analysis time was $\approx 30$ min per sample.

DATA ANALYSIS. Bartlett's test of homogeneity (Little and Hills, 1978) was used to confirm the homogeneity of variances in data from repeated experiments. The variances of the treatment observations were comparable in the two experiments and there were no differences in the treatment effects between experiments. Therefore, results from the two experiments were combined and the data were analyzed using SAS General Linear Models procedure (SAS Inst. Inc., 1994).

\section{Results}

Regardless of the N-form supplied to the purslane, the growth characteristics remained similar (Table 2). However, there were cultivar differences in growth with the green-leafed cultivar being taller, heavier, more branched and having a larger leaf area per plant than 'Goldberg'.

The leaf fatty acid composition of both purslane cultivars was similar and unaffected by $\mathrm{N}$-form supplied. The mean fatty acid composition (all expressed as percent of TFA $\pm \mathrm{SE}$ ) averaged across all $\mathrm{N}$-form treatments and both purslane cultivars was $14.4 \pm 0.7$ for palmitic (16:0), $3.2 \pm 0.3$ for palmitoleic $(16: 1), 1.1 \pm 0.1$ for stearic (18:0), $2.5 \pm 0.1$ for oleic $(18: 1), 11.1 \pm 0.2$ for linoleic $(18: 2)$, and $67.7 \pm 0.8$ for linolenic (18:3). LNA was the major fatty acid constituent making up two-thirds of the TFA. Further, the 16:3 fatty acid hexadecatrienoic acid was not detected in the leaves confirming 
Table 1. Concentration of inorganic nutrients (mM) used to prepare nutrient solutions at $\mathrm{NO}_{3}{ }^{-}-\mathrm{N}^{-} \mathrm{NH}_{4}{ }^{+}-\mathrm{N}$ ratios of 1:0, 0.75:0.25, 0.5:0.5, and 0.25:0.75. All nutrient solutions contained micronutients in the following concentrations (all in $\mu \mathrm{M}$ ): $\mathrm{B}, 25 ; \mathrm{Mn}, 2 ; \mathrm{Zn}, 2$; $\mathrm{Cu}, 0.5 ; \mathrm{Mo}, 0.5$; FeEDTA, 50 .

\begin{tabular}{|c|c|c|c|c|}
\hline \multirow{3}{*}{$\begin{array}{l}\text { Inorganic } \\
\text { nutrient }\end{array}$} & \multicolumn{4}{|c|}{$\mathrm{N}$ treatment } \\
\hline & \multicolumn{4}{|c|}{ Ratio of nitrate-N to ammonium-N in nutrient solution [concn (mM)] } \\
\hline & $1: 0$ & $75: 25$ & $50: 50$ & $25: 75$ \\
\hline $\mathrm{KNO}_{3}$ & 4.3 & 5.3 & & \\
\hline $\mathrm{Ca}\left(\mathrm{NO}_{3}\right)_{2}$ & 5.0 & 2.7 & 3.6 & 1.8 \\
\hline $\mathrm{MgSO}_{4}$ & 2.0 & 2.0 & 2.0 & 2.0 \\
\hline $\mathrm{KH}_{2} \mathrm{PO}_{4}$ & 1.0 & & & \\
\hline $\mathrm{NH}_{4}^{2} \mathrm{H}_{2} \mathrm{PO}_{4}$ & & 1.0 & 1.0 & 1.0 \\
\hline $\mathrm{NH}_{4} \mathrm{Cl}$ & & 2.6 & 6.2 & 9.7 \\
\hline $\mathrm{CaCl}_{2}$ & & 2.3 & 1.4 & 3.2 \\
\hline $\mathrm{KOH}$ & & & 5.3 & 5.3 \\
\hline
\end{tabular}

the report (Simopoulos et al., 1992) that purslane is an 18:3 plant.

$\mathrm{N}$-form had a pronounced influence on the concentrations of fatty acids in purslane leaves, but did not affect plant growth or fatty acid composition. The LNA and TFA concentrations of both purslane cultivars were lowest in plants exposed to $\mathrm{NO}_{3}{ }^{-}$as the sole $\mathrm{N}$ source (Table 3). Increasing $\mathrm{NH}_{4}{ }^{+}$in the nutrient solution from $0 \%$ to $50 \%$ of total $\mathrm{N}$ increased the average LNA 3.4-fold and TFA 3.1fold across both cultivars. However, increasing $\mathrm{NH}_{4}{ }^{+}$in the nutrient solution from $0 \%$ to $75 \%$ of total N only increased LNA 2.2-fold and TFA 2.1-fold in purslane leaves.

Increasing $\mathrm{NH}_{4}{ }^{+}$in the nutrient solution from $0 \%$ to $50 \%$ of total $\mathrm{N}$ only increased the leaf chlorophyll $47 \%$ in the green-leafed cultivar and $35 \%$ in 'Goldberg' (Table 3 ). The green-leafed purslane consistently had higher chlorophyll content than the golden-leafed 'Goldberg'. There was a highly significant positive correlation $\left[\mathrm{TFA}=3.89(\mathrm{Chl})-40.7, R^{2}=0.77,(P \leq 0.001)\right]$ between leaf chlorophyll concentration $\left(\mathrm{mg} \cdot \mathrm{g}^{-1} \mathrm{DW}\right)$ and leaf TFA content $\left(\mathrm{mg} \cdot \mathrm{g}^{-1} \mathrm{DW}\right)$ for the green-leafed cultivar, but a similar relationship was not observed with 'Goldberg'. Increasing $\mathrm{NH}_{4}{ }^{+}$in the nutrient solution from $0 \%$ to $50 \%$ of total $\mathrm{N}$ increased the TFA/chlorophyll ratio (w/w) from 0.9 to 2.1 for the green-leafed cultivar and from 1.4 to 2.7 for the golden-leafed 'Goldberg'. Increasing $\mathrm{NH}_{4}{ }^{+}$in the nutrient solution from $0 \%$ to $50 \%$ of total $\mathrm{N}$ only increased the thylakoid protein content $47 \%$ in the green-leafed cultivar and $63 \%$ in 'Goldberg'. However, the ratio of thylakoid protein to chlorophyll (Table 3 ) and the chlorophyll a/b ratio $[4.35 \pm 0.03$ (SE) averaged for both cultivars] were not altered by $\mathrm{N}$ form.

\section{Discussion}

Nitrogen form dramatically altered the fatty acid concentration in purslane leaves without altering fatty acid composition or thylakoid protein/chlorophyll ratio. These results show that the relative constancy of lipid molecular species in the leaf is essential for chloroplast function and hence preserved. The presence of $\mathrm{NH}_{4}^{+}-\mathrm{N}$ in the nutrient solution greatly increased leaf TFA, and modestly increased chlorophyll, and thylakoid protein concentrations, possibly by providing readily assimilable $\mathrm{N}$ that could stimulate chloroplast development. Raab and Terry (1994) reported that $\mathrm{NH}_{4}{ }^{+}-\mathrm{N}$ grown compared to $\mathrm{NO}_{3}{ }^{-}-\mathrm{N}$ grown sugar beets (Beta vulgaris L.) had doubled chloroplast volumes and greatly increased (4.3-fold) soluble leaf protein, but chlorophyll content increased by only $54 \%$. Golvano et al. (1982) reported greater length of internal plastid membranes of etioplasts of wheat (Triticum vulgare L. 'Ye'cora') seedlings given $\mathrm{NH}_{4}{ }^{+}-\mathrm{N}$ compared to $\mathrm{NO}_{3}{ }^{-}-\mathrm{N}$ nutrition. Perhaps one could attribute the increase in TFA observed in our study to further

Table 2. Plant growth characteristics of an unnamed green-leafed cultivar and a golden-leafed cultivar ('Goldberg') of Portulaca oleracea (purslane) grown in nutrient solutions with four nitrate $\left(\mathrm{NO}_{3}^{-}\right)$to ammonium $\left(\mathrm{NH}_{4}^{+}\right)$ratios. Data represent means of 10 observations.

\begin{tabular}{|c|c|c|c|c|c|c|}
\hline $\begin{array}{l}\mathrm{NO}_{3}^{-}: \mathrm{NH}_{4}^{+} \text {ratio in } \\
\text { nutrient solution }\end{array}$ & & $\begin{array}{l}\text { Shoot fresh wt } \\
(\mathrm{g})\end{array}$ & $\begin{array}{l}\text { Shoot dry wt } \\
(\mathrm{g})\end{array}$ & $\begin{array}{l}\text { Leaf dry wt } \\
(\mathrm{g})\end{array}$ & $\begin{array}{l}\text { Plant ht } \\
(\mathrm{cm})\end{array}$ & No. of shoots \\
\hline & & \multicolumn{5}{|c|}{ Green-leafed cultivar } \\
\hline $1: 0$ & & 42.4 & 1.7 & 0.8 & 39.8 & 13 \\
\hline $0.75: 0.25$ & & 41.4 & 1.7 & 0.8 & 39.8 & 12 \\
\hline $0.5: 0.5$ & & 38.9 & 1.6 & 0.7 & 37.6 & 11 \\
\hline \multirow[t]{2}{*}{$0.25: 0.75$} & & 39.4 & 1.6 & 0.7 & 37.9 & 12 \\
\hline & & \multicolumn{5}{|c|}{ Golden-leafed cultivar } \\
\hline $1: 0$ & & 32.2 & 1.4 & 0.6 & 25.7 & 6 \\
\hline $0.75: 0.25$ & & 33.6 & 1.4 & 0.6 & 26.0 & 7 \\
\hline $0.5: 0.5$ & & 32.5 & 1.3 & 0.6 & 25.3 & 7 \\
\hline $0.25: 0.75$ & & 30.6 & 1.2 & 0.6 & 23.5 & 7 \\
\hline Source of variation & df & F value & F value & F value & F value & F value \\
\hline $\mathrm{NO}_{3}^{-}: \mathrm{NH}_{4}^{+}$ & 3 & $0.5^{\mathrm{NS}}$ & $1.7^{\mathrm{NS}}$ & $1.1^{\mathrm{NS}}$ & $3.1 *$ & $0.4^{\mathrm{NS}}$ \\
\hline Cultivar & 1 & $25.1^{* * * *}$ & $31.8^{* * *}$ & $18.1^{* * * *}$ & $510.5^{* * *}$ & $276.8^{* * *}$ \\
\hline $\mathrm{NO}_{3}^{-}: \mathrm{NH}_{4}^{+} \times$cultivar & 3 & $0.2^{\mathrm{NS}}$ & $0.2^{\mathrm{NS}}$ & $0.1^{\mathrm{NS}}$ & $0.6^{\mathrm{NS}}$ & $1.9^{\mathrm{NS}}$ \\
\hline
\end{tabular}

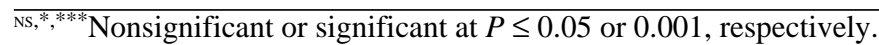


Table 3. Concentrations (all in $\mathrm{mg} \cdot \mathrm{g}^{-1}$ leaf DW) of whole-leaf chlorophyll (Chl), total fatty acids (TFA), $\alpha$-Linolenic acid and and thylakoid protein, and the ratios TFA/chlorophyll and protein/chlorophyll in leaves of an unnamed green-leafed cultivar and a golden-leafed cultivar ('Goldberg') of Portulaca oleracea (purslane) grown in nutrient solutions with four nitrate $\left(\mathrm{NO}_{3}^{-}\right)$to ammonium $\left(\mathrm{NH}_{4}^{+}\right)$ratios. Data represent means of 10 observations.

\begin{tabular}{|c|c|c|c|c|c|c|c|}
\hline $\begin{array}{l}\mathrm{NO}_{3}: \mathrm{NH}_{4}^{+} \text {ratio in } \\
\text { nutrient solution }\end{array}$ & & $\begin{array}{l}\text { Chlorophyll } \\
\left(\mathrm{mg} \cdot \mathrm{g}^{-1} \mathrm{DW}\right)\end{array}$ & $\begin{array}{c}\text { Total fatty acids } \\
\left(\mathrm{mg} \cdot \mathrm{g}^{-1} \mathrm{DW}\right)\end{array}$ & $\begin{array}{l}\alpha \text {-Linolenic acid } \\
\left(\mathrm{mg} \cdot \mathrm{g}^{-1} \mathrm{DW}\right)\end{array}$ & $\begin{array}{l}\text { Thylakoid protein } \\
\left(\mathrm{mg} \cdot \mathrm{g}^{-1} \mathrm{DW}\right)\end{array}$ & $\begin{array}{l}\text { TFA/Chl } \\
\text { ratio }^{z}\end{array}$ & $\begin{array}{l}\text { Protein/Chl } \\
\text { ratio }\end{array}$ \\
\hline & & \multicolumn{6}{|c|}{ Green-leafed cultivar } \\
\hline $1: 0$ & & 13.6 & 11.7 & 7.8 & 143 & 0.9 & 10.5 \\
\hline $0.75: 0.25$ & & 15.3 & 19.7 & 13.2 & 156 & 1.3 & 10.2 \\
\hline $0.5: 0.5$ & & 20.0 & 41.5 & 29.5 & 210 & 2.1 & 10.5 \\
\hline \multirow[t]{2}{*}{$0.25: 0.75$} & & 17.6 & 25.3 & 17.4 & 194 & 1.4 & 11.0 \\
\hline & & \multicolumn{6}{|c|}{ Golden-leafed cultivar } \\
\hline $1: 0$ & & 10.1 & 13.8 & 8.4 & 105 & 1.4 & 10.4 \\
\hline $0.75: 0.25$ & & 11.2 & 18.9 & 12.4 & 131 & 1.7 & 11.7 \\
\hline $0.5: 0.5$ & & 13.6 & 37.2 & 25.5 & 171 & 2.7 & 12.6 \\
\hline $0.25: 0.75$ & & 13.1 & 27.8 & 18.6 & 178 & 2.1 & 13.6 \\
\hline Source of variation & df & F value & $\mathrm{F}$ value & F value & $\mathrm{F}$ value & & \\
\hline $\mathrm{NO}_{3}^{-}: \mathrm{NH}_{4}^{+}$ & 3 & $19.2^{* * *}$ & $23.7^{* * * *}$ & $25.8^{* * *}$ & $9.6^{* * *}$ & & \\
\hline Cultivar & 1 & $86.7^{* * * *}$ & $0.02^{\mathrm{NS}}$ & $0.2^{\mathrm{NS}}$ & $8.0^{*}$ & & \\
\hline $\mathrm{NO}_{3}^{-}: \mathrm{NH}_{4}^{+} \times$cultivar & 3 & $1.6^{\mathrm{NS}}$ & $0.4^{\mathrm{NS}}$ & $0.5^{\mathrm{NS}}$ & $0.3^{\mathrm{NS}}$ & & \\
\hline
\end{tabular}

${ }^{\mathrm{z} S t a t i s t i c a l}$ analyses were not conducted on TFA/Chl or protein/Chl ratios. Ns, ${ }^{* * * * *}$ Nonsignificant or significant at $P \leq 0.05$ or 0.001 , respectively.

enlargement of purslanes already large chloroplasts by $\mathrm{NH}_{4}{ }^{+} \mathrm{N}$ nutrition. However, Palaniswamy (1998) found that, under certain environmental conditions, the majority of LNA recovered in purslane leaves was not associated with thylakoid membrane.

Although others (Tchang et al., 1985; Tremolieres, 1972; and Tremolieres et al., 1973) found that LNA was synthesized in a fixed ratio to chlorophyll in Pisum sativum, this relationship was not observed with purslane. Furthermore, 'Goldberg' and the greenleafed cultivar had similar TFA and LNA concentrations, but 'Goldberg' had consistently lower chlorophyll concentration than the green-leafed cultivar. These data suggest that the relatively short-term (18 d) exposure of purslane to $\mathrm{NH}_{4}{ }^{+} \mathrm{N}$ in the nutrient solution stimulated fatty acid synthesis in excess of that associated with thylakoid development.

The uncoupling of TFA accumulation from chlorophyll and thylakoid protein synthesis by $\mathrm{NH}_{4}{ }^{+} \mathrm{N}$ in the nutrient solution suggests that accumulation of TFA is not associated solely with thylakoid membranes in the fatty acid-rich species Portulacaoleracea (purslane). Indeed, we observed the presence of osmophilic lipid globules in purslane chloroplasts indicating the capacity for fatty acid storage (Palaniswamy, 1998). Perhaps purslane stores significant amounts of TFA in its large chloroplasts, which could account for its exceptionally high concentration of TFA compared to other green leafy vegetables.

The relatively low fatty acid concentration in purslane plants exposed to $\mathrm{NO}_{3}{ }^{-}$as the sole $\mathrm{N}$ source may result from impaired assimilation of $\mathrm{NO}_{3}{ }^{-}$to ammonium. Ammoniacal $\mathrm{N}$ can be used directly by plants in the synthesis of amides and amino acids, whereas $\mathrm{NO}_{3}^{-}-\mathrm{N}$ has to be reduced by processes that command up to $25 \%$ of either photosynthetic or mitochondrial electron transport capacity (Bloom et al., 1989). Perhaps the reduction of $\mathrm{NO}_{3}^{-}$ proceeds too slowly to maximize chloroplast development in young leaves. The relative decline in TFA of young leaves of plants grown in the $75 \% \mathrm{NH}_{4}{ }^{+}-\mathrm{N}$ solution compared to those in the $50 \% \mathrm{NH}_{4}{ }^{+} \mathrm{N}$ solution could be an adverse effect of accumulation of some unassimilated ammonia. Or perhaps the modest decline in leaf TFA in plants grown with $75 \% \mathrm{NH}_{4}{ }^{+}(0.25: 0.75)$ compared to the $0.5: 0.5$
$\mathrm{NO}_{3}{ }^{-}-\mathrm{N}: \mathrm{NH}_{4}{ }^{+}-\mathrm{N}$ ratio could be due to preferential catabolism of the fatty acids, over protein. An increase in catabolism of lipids, carbohydrates, and proteins (as respiratory substrates) had been observed in $\mathrm{NH}_{4}{ }^{+} \mathrm{N}$ grown plants of radish (Raphanus sativus $\mathrm{L}$.) (Goyal et al., 1982) and white mustard (Sinapis alba L.) (Mehrer and Mohr, 1989).

Lack of a growth response in purslane to increased $\mathrm{NH}_{4}{ }^{+} \mathrm{N}$ fertilization may be related directly to the relatively high metabolic investment associated with increased lipid anabolism as well as the effects of N-form on photosynthesis. Raab and Terry (1994) also found that the photosynthetic rate per chlorophyll molecule was reduced for enlarged chloroplasts and suggested this was due to increased $\mathrm{CO}_{2}$ diffusion resistance within the chloroplasts. However, at $P P F$ levels above $1000 \mu \mathrm{mol} \cdot \mathrm{m}^{-2} \cdot \mathrm{s}^{-1}$ and elevated carbon dioxide levels, they found that the photosynthesis rate per unit leaf area was higher in $\mathrm{NH}_{4}{ }^{+}$-grown than $\mathrm{NO}_{3}^{-}$-grown plants. In our study, purslane was exposed to $\mathrm{N}$-form treatments for only $18 \mathrm{~d}$ and under ambient carbon dioxide and relatively low $P P F$ conditions. Marschner (1995) indicated that the optimum proportion of $\mathrm{N}$-form for best growth is dependent on root zone temperature, light intensity (irradiance), and total concentration of $\mathrm{N}$ supplied. Therefore the optimum proportion of $\mathrm{N}$-form for purslane growth will probably vary with environmental conditions; however, it is apparent that $\mathrm{NH}_{4}{ }^{+}$-N in the nutrient solution dramatically stimulates TFA accumulation in a relatively short period of time, and hence improves the nutritional value of the harvested product with respect to essential fatty acids.

\section{Literature Cited}

Allen, C.F., O. Hirayama, and P. Good. 1966. Lipid composition of photosynthetic systems, p. 195-200. In: T.W. Goodwin (ed.). Biochemistry of chloroplasts. vol 1. Academic Press, New York.

Arnon, D.I. 1949. Copper enzymes in chloroplasts. Polyphenoloxidases in Beta vulgaris. Plant Physiol. 24:1-14.

Barta, A.L. 1975. Higher fatty acid content of perennial grasses as affected by species and by nitrogen and potassium fertilization. Crop Sci. 15:169190. 
Berkowitz, G.A. and M. Gibbs. 1985. Chloroplasts as a whole, p. 153-181 In: F. Linskens and J.F. Jackson. (eds.). Modern methods of plant analysis. New series vol. 1. Cell components. Springer-Verlag, Berlin.

Bloom, A.J., R.M. Cladwell, J. Finazzo, R.L. Warner, and J. Weissbart. 1989. Oxygen and carbon dioxide fluxes from barley shoots dependent on nitrate assimilation. Plant Physiol. 91:352-356.

British Nutrition Foundation. 1993. Unsaturated fatty acids: Nutritional and physiological significance: The report of the British Nutrition Foundation's task force. Chapman and Hall, London.

Chapman, D.J., J. De-Felice, and J. Barber. 1983. Influence of winter and summer growth conditions on leaf membrane lipids of Pisum sativum $\mathrm{L}$. Planta 157:218-223.

Crombie, W.M. 1958. Fatty acids in chloroplasts and leaves. J. Expt. Bot. 9:254-261.

Golvano, M.P., M.R. Felipe and A.M. Cintos. 1982. Influence of nitrogen sources on chloroplast development in wheat seedlings. Physiol. Plant. 56:353-360.

Goyal, S.S., O.A. Lorenz, and R.C. Huffaker. 1982. Inhibitory effects of ammoniacal nitrogen on growth of radish plants. I. Characterization of toxic effects of $\mathrm{NH}_{4}^{+}$on growth and its alleviation by $\mathrm{NO}_{3}^{-}$. J. Amer. Soc. Hort Sci. 107:125-129.

Green, J.L. and W.D. Holley. 1974. Effect of $\mathrm{NH}_{4}^{+}: \mathrm{NO}_{3}^{-}$ratio on net photosynthesis of carnation. J. Amer. Soc. Hort. Sci. 99:420-424.

Inskeep, W.P. and P.R. Bloom. 1985. Extinction coefficients of chlorophyll $\mathrm{a}$ and $\mathrm{b}$ in $\mathrm{N}, \mathrm{N}$-dimethylformamide and $80 \%$ acetone. Plant Physiol. 60:606-608.

Lepage, G. and C.C. Roy. 1986. Direct esterification of all classes of lipids in a one step reaction. J. Lipid Res. 27:114-120.

Little, T.M. and F.J. Hills. 1978. Agricultural experimentation: Design and analysis. Wiley, New York.

Lowry, O.H., N.J. Rossenbrough, A.L. Farr, and R.J. Randall. 1951. Protein measurement with the Folin phenol reagent. J. Biol. Chem. 193:265-275.

Marschner, H. 1995. Mineral nutrition of higher plants. 2nd ed. Academic Press, New York.

Maxwell, R.J., W.N. Marmer, M.P. Zubillage, and G.A. Dalickas. 1980. Determination of total fat in meat and meat products by a rapid, dry column method. J. Assn. Offic. Anal. Chem. 63:600-603.

Mehrer, I. and H. Mohr. 1989. Ammonium toxicity: Description of the syndrome in Sinapis alba and the search for its causation. Physiol. Plant. 77:545-554.

Palaniswamy, U. R. 1998. Enhancement of naturally occurring chemopreventive compounds in salad greens through environmental manipulation during crop growth. PhD diss., Univ. Conn., Storrs.

Piorreck, M., K.H. Baasch, and P. Pohl. 1984. Biomass production, total protein, chlorophylls, lipids and fatty acids of fresh water green and blue-green algae under different nitrogen regimes. Phytochemistry 23:207-216.

Pohl, P., T. Passig, and H. Wagner. 1971. Uber den Einfluss von anorganischem Stickstoff-gehalt in der Nahrlosung auf die Fettsaurebiosynthese in Grunalgen. Phytochemistry 10:1505.

Raab, T.K. and N. Terry. 1994. Nitrogen source regulation of growth and photosynthesis in Beta vulgaris L. Plant Physiol. 105:1159-1166.

Regnault, A., D. Chervin, A. Chammai, F. Piton, R. Calvayrac, and P. Mazliak, 1995. Lipid composition of Euglena gracilis in relation to carbon-nitrogen balance. Phytochemistry 40:725-733.

Simopoulos, A.P. 1991. Omega-3 fatty acids in health and disease and in growth and development. Amer. J. Clinical Nutr. 54:438-463.

Simopoulos, A.P, R.R. Kifer, and R.E. Martin (eds.). 1985. Health effects of polyunsaturated fatty acids in seafoods. Academic Press, Orlando, Fla.

Simopoulos, A.P., H.A. Norman, J.E. Gillapsy, and J.A. Duke. 1992. Common purslane: A source of omega-3 fatty acids and antioxidants. J. Amer. College Nutr. 11:374-382.

Simopoulos, A.P. and N. Salem, Jr. 1986. Purslane: A terrestrial source of omega-3 fatty acids. New England J. Med. 315:833.

Tchang, F., A. Connan, D. Robert, A. Tremolieres. 1985. Effects of light and temperature on $\alpha$-linolenic acid biosynthesis in developing cotyledons of Pharbitis nil. Physiol. Veg. 23:361-371.

Tremolieres, A. 1972. Biosynthese de l'acide linolenique dans la feuille de pois. Phytochemistry 11:3453-3460.

Tremolieres, A., T. Guillot-Salomon, J.P. Dubacq, R. Jacques, P. Mazliak, and M. Signol. 1979. The effect of monochromatic lights on linolenic and trans-3 hexadecenoic acid biosynthesis and its correlation to development of the plastid lamellar system. Physiol. Plant. 45:429436.

Tremolieres, A., R. Jacques, and P. Mazliak. 1973. Regulation par la lumiere de l'accumulation de l'acide linolenique dans la jeune feuille de Pois. Spectre d'action, influence de l'intensite' de l'eclairement. Physiol.Veg. 11:239-251.

Vengris, J., S. Dunn, and M.S. Sapunckis. 1972. Life history studies as related to weed control in the northeast. 7. Common purslane. Northeast Regional Publ, The Univ. Mass., Amherst. Res. Bul. 598:1-45.

Wolff, I.A. 1966. Seed lipids. Science 154:1140-1149. 